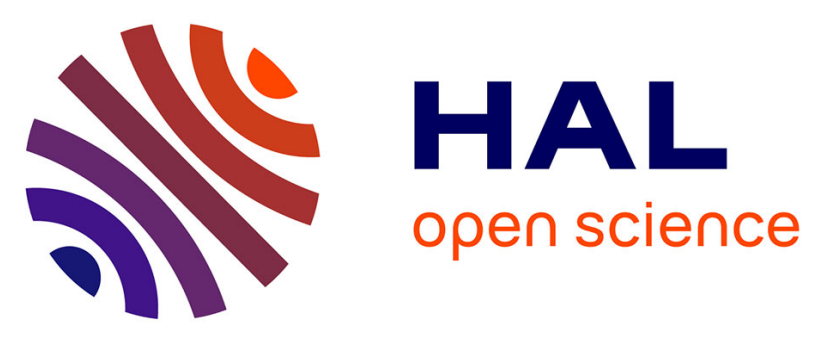

\title{
Serious games to teach social interactions and emotions to individuals with autism spectrum disorders (ASD)
}

Charline Grossard, Ouriel Grynszpan, Sylvie Serret, Anne-Lise Jouen, Kevin Bailly, David Cohen

\section{- To cite this version: \\ Charline Grossard, Ouriel Grynszpan, Sylvie Serret, Anne-Lise Jouen, Kevin Bailly, et al.. Serious games to teach social interactions and emotions to individuals with autism spectrum disorders (ASD). Computers and Education, 2017, 113, pp.195-211. 10.1016/j.compedu.2017.05.002 . hal-01525828}

\section{HAL Id: hal-01525828 \\ https: / hal.sorbonne-universite.fr/hal-01525828}

Submitted on 22 May 2017

HAL is a multi-disciplinary open access archive for the deposit and dissemination of scientific research documents, whether they are published or not. The documents may come from teaching and research institutions in France or abroad, or from public or private research centers.
L'archive ouverte pluridisciplinaire HAL, est destinée au dépôt et à la diffusion de documents scientifiques de niveau recherche, publiés ou non, émanant des établissements d'enseignement et de recherche français ou étrangers, des laboratoires publics ou privés. 


\section{Serious games to teach social interactions and emotions to individuals with autism spectrum disorders (ASD)}

Charline Grossard ${ }^{1}$, Ouriel Grynspan ${ }^{2}$, Sylvie Serret ${ }^{3}$, Anne-Lise Jouen ${ }^{2}$, Kevin Bailly ${ }^{2}$, and David Cohen $^{1,2^{*}}$

${ }^{1}$ Department of Child and Adolescent Psychiatry, AP-HP, Groupe Hospitalier Pitié-Salpêtrière, Université Pierre et Marie Curie, 47 bd de l'Hôpital, 75013, Paris, France

${ }^{2}$ Institut des Systèmes Intelligents et Robotiques, CNRS UMR 7222, Université Pierre et Marie Curie, 1 place Jussieu, 75005, Paris, France

${ }^{3}$ Department of Child and Adolescent Psychiatry et Centre de Ressource Autisme, Université de Nice, Fondation Lenval, 57 Avenue de la Californie, 06200, Nice, France

*Corresponding author at: Department of Child and Adolescent Psychiatry, APHP, CNRS UMR 8189, Groupe Hospitalier Pitié-Salpêtrière, Université Pierre et Marie Curie, 47-83 bd de l'Hôpital, F-75651 Paris cedex 13, France.

Tel.: + 331421623 51; fax: + 33142162353 .

E-mail address: david.cohen@psl.aphp.fr (D. Cohen).

${ }^{1}$ Address: Groupe Hospitalier Pitié-Salpêtrière, 47-83 bd de l'Hôpital, F-75651 Paris cedex 13, France.

Short title: Serious games and ASD

\section{Word count}

Abstract: 243 words

Text: 4475 words

Tables: 3; Figures: 3

Supplemental materials: 1

References: 71 
Serious games to teach social interactions and emotions to individuals with autism spectrum disorders (ASD)

Short title: Serious games and ASD

Word count

Abstract: 243 words

Text: 4475 words

Tables: 3; Figures: 3

Supplemental materials: 1

References: 75 


\section{Abstract:}

The use of information communication technologies (ICTs) in therapy offers new perspectives for treating many domains in individuals with autism spectrum disorders (ASD) because they can be used in many different ways and settings and they are attractive to the patients. We reviewed the available literature on serious games that are used to teach social interactions to individuals with ASD. After screening the Medline, Science Direct and ACM Digital Library databases, we found a total of 31 serious games: 16 that targeted emotion recognition or production and 15 that targeted social skills. There was a significant correlation between the number of reports per year and the year of publication. Serious games appeared promising because they can support training on many different skills and they favour interactions in diverse contexts and situations, some of which may resemble real life. However, the currently available serious games exhibit some limitations: (i) most of them are developed for High-Functioning individuals; (ii) their clinical validation has rarely met the evidence-based medicine standards; (iii) the game design is not usually described; and, (iv) in many cases, the clinical validation and playability/game design are not compatible.

Future research agendas should encompass (i) more robust studies in terms of methodology (large samples, control groups, longer treatment periods, follow-up to assess whether changes remain stable, etc.) to assess serious game efficacy; (ii) more collaboration between clinical and computer/game design experts; and (iii) more serious games that are adapted to Low-Functioning ASD individuals.

Keywords: Autism, Information Communication Technologies, Serious Games, Evidencebased Medicine, social skills. 


\section{Introduction}

Autism spectrum disorders (ASD) are developmental disorders that affect individuals to different degrees. The core symptoms include impairments in communication and social interactions, with deficits in social emotion reciprocity, in non-verbal communication and in developing and maintaining relationships, all of which fall under the umbrella term of "social skills". Social skills can be defined as "the ability to perform those behaviours that are important in enabling a person to achieve social competence" [64]. They include verbal (e.g. speech intonation, clarity of speech) and also non-verbal behaviours (e.g. eye-contact, facial expression, gestures). These behaviours have to be combined in order to achieve complex social goals such as initiating an interaction or selecting appropriate topics for conversation. Thereby, disabilities in these skills complicate the integration of persons with ASD into schools and society. Teaching social skills to individuals with ASD is a considerable challenge. Recently, many studies have considered the use of information communication technologies (ICTs) in therapy [14]. Indeed, children with ASD enjoy playing video games, just as many typical children do [24]. They commit to virtual environments because they are predictable and reassuring [48]. Moreover, technology is a way to easily re-create different situations of normal life, and, as such, they provide many possibilities for the therapist [40]. In this context, the use of virtual environments enables practice with social situations that closely approximate real life.

ICT-based interventions can be classified in three main categories [14]. First, iPods and iPads Apps aims to facilitate a specific aspect in social life. Kagohara et al. recently review the literature on App used in individuals with developmental disabilities including ASD [41]. Despite some promising apps (e.g. Rubycube apps or Social Detective App), most available apps have received limited empirical clinical validation. The 15 studies reported by Kagohara et al. encompassed only 47 individuals in total [41]. Second, ICT-interventions 
include the use of robots with children with $\operatorname{ASD}[14,23,38,59]$. In this sub-domain, clinical validation is also limited as many studies focused on the development of novel social skills for robots thus narrowing down the expectation for social training [38]. Finally, ICTinterventions include serious games. Serious games can be described as "digital games and equipment with an agenda of educational design and beyond entertainment" [51]. Many serious games have been created to improve social interactions in individuals with ASD. They exist on multiple supports or platforms: computers, tabletop formats, robots, etc. Despite exciting preliminary results, the use of serious games in ASD remains limited [56]; most of the current serious games dedicated to ASD have limited relevance to the actual interactive conditions of real life experiences, and they have often not been validated beyond proof-ofconcept studies [14]. Continued research is needed to provide a definitive answer about their efficacy and generalisation to everyday life [32].

Several reviews have focused on serious games $[49,50,55,56,58,70]$. However, none were exhaustive, as they usually targeted some specific aspects of serious games (e.g., domains of training [49], methods and results [58]), and none described the games' design and playability. The accumulated evidence from meta-analytical screening suggests that ICTbased interventions are indeed effective [34]. The present review seeks to supplement the current state of knowledge by examining the gaming and educational design of the software used in these interventions. Therefore, it focuses on the notion of "serious games".

Here, our aim was to review the literature on the serious games that are used to teach social interactions to individuals with ASD, focusing on the principles and theory that underlie the games, their clinical validation as well as their playability and design.

\section{Methods}




\subsection{Search procedure / analysis}

Between January and June 2014, we performed a computerised search of the Medline (PubMed version), Science Direct and ACM Digital Library databases. In all three, the search was limited to articles written in English and published in peer-reviewed journals between January 2001 and April 2014. The search used the following keywords: autism or ASD and "serious games" or "video games" or "games" or "virtual reality". We screened all identified reports, studies and reviews by reading the titles and abstracts. In addition, the reference lists of the studies that met the inclusion criteria were reviewed to identify additional studies for inclusion. Finally, we added one paper that had been submitted by our group and that described a novel gaming platform to improve social skills in ASD (Bono et al., in revision) [13].

\subsection{Inclusion procedure}

The studies included in the analyses met the following criteria: (i) they reported on serious games on computers (including tabletop computers); (ii) they reported on serious games that trained on social interactions; and (iii) they targeted individuals with ASD. We excluded the current applications on digital tablets that did not match the definition of a serious game (“digital games and equipment with an agenda of educational design and beyond entertainment"). We also excluded all games that were only cited in reviews and not described in the scientific literature (such as games that are only available on the web). Figure 1 summarises the flowchart of the study. We ultimately found 40 studies on 31 serious games that corresponded to our criteria; some games were mentioned in more than one paper.

\subsection{Data extraction and quality quantification}


For each selected study, we extracted the targeted skills and populations, as well as the games' designs and principles. We also examined whether the game was based on a specific treatment model (e.g., theory of mind, applied behaviour analysis, etc.) and whether it had been tested in a clinical population. To assess the quality of the clinical validation, we extracted the following study variables (population, duration, study design (e.g., open trial vs controlled study training)) and scored it according to the Connolly, Boyle, MacArthur, Hainey \& Boyle (2012) scale [20]. The Connolly et al. scale focuses on the following criteria: the type of study, method and analysis, generalisability (size and representativeness of the sample), pertinence, and confidence in the results. We pooled the data for each game from the corresponding studies. Each game received a rate for each criterion $(3=$ high; $2=$ medium; $1=$ low) and a total score (maximum=15). We also summarised the main results of each study.

To better characterize the games, we also summarised the attributes of each serious game based on Yusoff's (2010) work [74]. Yusoff proposed a conceptual framework that describes a list of attributes based on cognitive, behaviourist and constructivist theories that the serious games' creators may use to reach their educational agenda. These attributes include: incremental learning, linearity, attention span, scaffolding, transfer of learned skills, interaction, learner control, practice and drill, intermittent feedback, reward, situated and authentic learning, and accommodating the learner. They are described in Table 1. We built a scale based on these attributes by rating each game and its attributes ( 0 if the attribute is absent, 1 if it is partly present, and 2 if it is fully present). We rated a total score by summing the attributes' ratings (maximum score=24). Here, a higher total score does not indicate a higher conceptual quality, but rather higher conceptual complexity and that the authors' provided a better description given for their game. The data were blindly extracted by two of the co-authors (CG and AJ). The intraclass correlation coefficients (ICCs) were excellent for the total Connolly scale ( $\left.\mathrm{ICC}_{\text {Connolly Total }}=0.95\right)$ and Yusoff scale $\left(\mathrm{ICC}_{\text {Yusoff Total }}=0.90\right)$ scores. 
The subscores of the Connolly scale had good to excellent ICCs, ranging from 0.72 to 0.94 , with the exception of the pertinence criterion $\left(\mathrm{ICC}_{\text {Connolly pertinence }}=0.36\right)$. The subscores of the Yusoff scale had good to excellent ICCs, ranging from 0.62 to 0.94 . We found a weak correlation between the total scores from the Yusoff and Connolly scales $(r=0.3, p=0.1)$, indicating that the two instruments did not measure the same characteristics.

INSERT FIGURE 1 HERE

INSERT TABLE 1 HERE

\section{Results}

We found a total of 31 serious games that were designed to improve social skills. Sixteen of these games specifically targeted facial emotion recognition or production and 15 were aimed at training on more general social skills, such as interaction, collaboration, and adaptation to specific social contexts. Beginning in 2001, there was an increase in publications (Fig 2); we found a significant correlation between the number of articles per year and the year of publication $(\rho=0.65, p<0.05)$. Seventeen additional games were only available through the internet (16 games and 1 online community) and had no clinical validation. They are described in Annex 1. To simplify the presentation, we elected to separate the 31 games as a function of the game target (facial emotion vs. general social skills).

INSERT FIGURE 2

\subsection{Games targeting emotion recognition or production}

Although social skills required in real life involve rich combinations of perspective taking, emotional regulation, cognitive flexibility, appropriate use of language and so on, the literature search conducted here emphasized that a significant part of the effort devoted to 
serious game design has been focusing on the basic ability of emotion recognition, which sustains those more complex forms of social competencies. Table 2 summarises the main characteristics of the 16 games that specifically targeted emotion recognition. Many of these games focus on recognising emotions in pictures, drawings, audio or video recordings. Although emotion recognition is multimodal in nature [69], visual facial stimuli were the most frequent, audio stimuli were less frequent and body posture presentations were only proposed once. Four games also trained on producing emotions, often by having individuals mimic a model. Among them, only LifeIsGame [26] includes emotion production exercises in a social context with no visual support. Professionals in autism (such as clinicians and developmental disorder and education professionals) were involved in designing the games, with the exception of two games that were created by students in computer sciences $[51,65]$.

Supplementary Table S1 summarises the scale scoring from the Connolly et al. study regarding clinical validation. Excellent scores $(\geq 12)$ were obtained for The Junior Detective Program [9], Emotion Trainer [66], FaceSay2 [39], JeStimule [61], Let's Face It [66], Mind Reading [31] and The Transporters [30]. Regarding the targeted populations, 6 serious games are available exclusively for high-functioning (HF) ASD or Asperger syndrome (AS) individuals, with no adaptation for low-functioning (LF) ASD patients. Two other games require that players have good reading skills. Among the 16 games, 10 were assessed in populations with ASD. Only 7 studies used a control group, including a few with sample sizes of 30 or more children per group. Only 4 studies were randomised (Table 1). As a result, we only found one study (which assessed the serious game Let's Face It!) [66] that included both a control group and an ASD group matched for developmental age and diagnosis (AS or PDD-NOS) and more than 30 children per group. In terms of efficacy, the individuals who played Mind Reading [31], The Transporters [30], JeStimule [61], FaceSay2 [39], The Junior Detective Program [9], and Emotion Trainer [66] showed improvement after training but their 
results cannot be extended to the whole spectrum of autism disorders given the limited representativeness of their samples. Also, no study showed evidenced of clinical relevance meaning that by playing with a serious game that focuses on social interaction skills, the children were not shown to improve clinical social interaction scores (like ADOS or Vineland).

Supplementary Table S2 summarises the presence or absence of the different attributes of serious games described by Yusoff (2010) [74]. Games usually included several attributes (mean=8.5; range: 5-11). However, three attributes appeared to be used less frequently: attention span, reward and accommodating the learner. Each game was very different with variations based on the authors' choices. To illustrate this diversity, we briefly describe two games. The first game, CopyMe [65], is very simple in its architecture and principles and has not been tested in a clinical study. The second, JeStimule [61], is more complex in its computation and was tested in an open stratified clinical trial. The first game, CopyMe [65], targets only facial expression production; the game is designed for an iPad. The player must look at a picture of a facial expression with the name of the expression written underneath it and then she/he has to reproduce it. There are 3 levels of difficulty: the easy level includes happy and sad emotions; the intermediate level includes happy, sad, angry and surprised; and the difficult level includes happy, sad, angry, surprised, scared and yucky. A facial expression recogniser was built for this game.

The second game, JeStimule [61], is a computer game that targets expression recognition in context. This game is separated into 2 modes, training and the game itself. The particularity of this game is that it is possible for LF-ASD (Low Functioning Autism Spectrum Disorders) individuals to play using colour codes that are associated with specific emotions (yellow for joy, for example). Players learn these codes in the training mode. During the game, the player moves her/his avatar in a $3 \mathrm{D}$ environment and is exposed to different 
scenarios during which she/he has to recognise an emotion. Different levels of recognition exist: (1) recognizing the emotion expressed by a virtual character due to a specific event (e.g. a child falls down); (2) the same task but the face of the virtual character is hidden; (3) recognizing the emotion conveyed by the non-verbal communicative behaviour of a virtual character speaking with another virtual character when the verbal exchange is made inaudible.

\section{INSERT TABLE 2}

\subsection{Games that target general social skills}

Table 3 summarises the main characteristics of the 15 games that target general social skills; the majority (7/15) focused on collaborative skills (negotiation, turn taking, planning together, etc.). These seven serious games were based on the principle that cooperative games support social skills and force participants to communicate and work together in order to finish the game. The rules in these games did not allow players to succeed alone. Each individual required the intervention of another participant to move forward; the 2 players had to execute actions together, with each player controlling separate elements of the game. Therefore, players had to interact with each other in order to accomplish the tasks. The seven other games provided training on appropriate behaviours in specific social situations (café, birthday party, etc.); these games relied on virtual environments. Finally, one game focused on the child's responses and initiative actions with a virtual character in a virtual interactive garden.

Supplementary Table S3 summarises the scoring scale from the Connolly et al. study regarding clinical validation. None of the games reached excellent scores $(\geq 12)$, indicating that the clinical validation is rather limited in this group of games (mean=8.53; range: 7-11). Indeed, although autism professionals were involved in the design of all of these games, 8 games were designed exclusively for HF-ASD (High Functioning Autism Spectrum 
Disorders) or AS (Asperger) individuals, 11 were assessed on a sample of individuals with ASD, only 2 studies included a control group, and none of the clinical studies included samples of more than 30 individuals with ASD or were randomised (Table 2).

Supplementary Table S4 summarises the presence or absence of the different attributes of serious games described by Yusoff (2010) [74]. The games usually had several attributes (mean=8.73; range: 6-12). However, four attributes appeared to be used less frequently: incremental learning, attention span, reward and accommodating the learner.

The games were designed in different ways and aimed to train on different skills. For example, the Cooperative Puzzle Game aimed to train on collaborative skills [6]. This game used the Diamond touch, a multi-user screen that can support small group collaboration, where 2 players have to assemble a puzzle using a model; the pieces could only be moved through a joint action performed by the 2 players. The Cooperative Puzzle Game included 6 puzzles (extracted from the movie "Shrek 2") arranged by level of difficulty, and the levels were defined after testing with typical boys. Another example is a game that relied on collaborative virtual learning environments [16] and intended to enhance empathy. The player operated an avatar in a virtual fast-food restaurant, with the help of a clinician. S/he interacted with a teacher who played her/his own avatar in the game. Four social scenes were used (someone jumps ahead in a restaurant queue; someone comes in and sits down in an unoccupied seat next to the subject while the subject is eating; a drink is spilled on the floor; or a passer-by slips and falls). During the game, the virtual characters asked questions by text or voice on the participants' feelings regarding the unexpected events related to the scenarios. The teacher helped the player to understand and answer correctly.

INSERT TABLE 3

\section{Discussion}


Even when we excluded current smartphone and iPad applications that did not correspond to the narrow definition of a serious game from our study, we found that many serious games had been proposed for training or overcoming social interaction impairments in individuals with ASD since the year 2000. The number of serious games has even increased in the last few years; 23 of the papers that were reviewed in the current report were published in 2010 or later (Fig 2). In total, we found 31 games that aim to help people with ASD manage social interactions. The majority targeted children or adolescents with ASD. However, adults with ASD also face challenges in social cognition and interactions but have received less attention in the serious game research community [15].

Many games are intended for people with HF-ASD (e.g., [29]) or AS (e.g., [48]), whereas many individuals with ASD have comorbid intellectual disability [4]. Some games require good reading skills and are, therefore, not accessible to a large portion of those on the spectrum (e.g., [30]). A small number of games attempt to work around this challenge with oral explanations. However, for most people with ASD, oral comprehension is difficult, and they might find it hard to play with these games. The focus of training with these individuals tends to emphasize basic communication needs such as attention to faces and eye-contact. Unfortunately, only a few serious games have addressed such basic nonverbal skills that are nevertheless relevant for HF and LF ASD. This is a major limitation in terms of serious game availability for the broad spectrum of individuals with ASD.

Nearly all serious games that have been reported in research papers have included at least one ASD expert in the game design. They are only two exceptions [51,65], and the quality of these works may be questionable. In another report [42], the therapeutic support was provided by an online game that was not dedicated to ASD. Even if part of the game was customized by professionals specifically for ASD and included only what they consider of interest in terms of education needs, the potential benefits for ASD remained limited. 
A major limitation in the current literature is the lack of or limited clinical validation. As shown in Tables 2 and 3 (Connolly scale total scores), among the 31 games described in this review, $16.1 \%(\mathrm{~N}=5)$ were not tested on subjects with ASD. For another $12.5 \%(\mathrm{~N}=4)$, we only found studies that assessed the games' usability in small samples of individuals with ASD. The studies described whether the players enjoyed the games, but did not report whether the interventions produced any changes in their social skills. For the last group of studies $(\mathrm{N}=22)$, the effects of the interventions on social abilities were assessed. However, based on evidence-based guidelines, the overall quality of these clinical studies is poor [60]. For the majority of the studies, the samples are too small to allow us to draw conclusions on any real effects of the computer games. Moreover, a large part of the games were tested for short periods that were not sufficient to assess the interventions' long-term efficacy [15]. A number of authors have already observed that longitudinal studies are warranted in this field $[68,75]$. In addition, many studies did not include a control group that matched the exposed group (e.g., [11]). Another important issue is the transfer of acquired social skills to everyday life. In many cases, the pre- and post-treatment measures focused on the skills that were directly targeted in the serious games. However, working on discrete social abilities is only a first step towards improving social communication skills. For instance, although memorizing and identifying facial expressions can be considered a building block of nonverbal communication, it provides no guarantee that the individual will be able to process the emotional information thus retrieved to engage fluidly in an ongoing and ever-changing social interaction. Therapists or teachers generally agree that effective interventions should produce improvements in social skills in real-world situations [61]. As a consequence, more research should be developed to assess the link between serious game interventions and improvements in real-life. 
Another limitation is the difficulty in defining a serious game. Most of the studies focused on the therapeutic objectives and did not pay attention to the accessibility and enjoyability of the game. Most of the games are designed like exercises, without all of the characteristics of a video game. For many studies, we do not have much information about the design process of the game and can only find the methods and results for the behavioural and cognitive testing. Notwithstanding, some of the studies describe how the game was designed (e.g., Piper, O'Brien Morris \& Winograd [54]). However, most of these studies did not evaluate the impact of the game on the social skills of individual with ASD. Indeed, figure 3 shows both the total Yusoff and Connolly scores for each game. As shown here, we found a weak positive relationship between the two total scores, indicating that the researchers who pay attention to the validity of the methods and results are not necessarily those who care about the ergonomics and usability of serious games. An interpretation may be that the fields of developmental psychology and child psychiatry do not interact efficiently with the fields of engineering and the serious game specialty.

\section{INSERT FIGURE 3}

This lack of interest in design coincides with the lack of framework describing how to create a serious game for teaching social skills to individuals with ASD. To date, different frameworks for designing serious games have been proposed. They detail the design process to help the team during the different steps of game creation $[21,46,72]$. The existing frameworks focus on integrating behavioural and cognitive models within the game [74]. However, these frameworks do not usually focus specifically on ASD or teaching social skills. Recently yet, Khowaja \& Salim [43] tried to summarize the main components of ASD serious game design. 
The lack of frameworks explains the heterogeneity between serious games. It also complicates the manner in which we evaluated the design of the different serious games. In this review, we used Yusoff's [74] proposal to evaluate the presence of the different attributes of serious games. In his work, the search for these attributes enables the rater to judge the quality by describing how the authors designed a serious game. Therefore, the raters' scores depend on the description of the game in the paper and its overall complexity (as evidenced by the number of attributes found). This can be a limitation for this work, especially because many authors focused on the clinical study methods and testing rather than describing the game operation.

Despite these limitations, we believe that the use of ICTs may offer opportunities for individuals with ASD. A recent meta-analysis that focused on ICTs that had been tested in controlled trials $(\mathrm{N}=14)$ found that remediation through serious games was effective [35]. The authors included all types of serious games (including those targeting language skills, reading, spatial planning, emotions, and general social skills) in their meta-analysis and used the mean effect sizes of the studies' primary variables to assess any pre- and post-treatment changes. The efficacy in the controlled studies $(\mathrm{N}=14)$ was significant, with a mean effect size approaching the medium range. Regarding social skills training, our review included 6 games that suggested promising results in at least one controlled trial that included nearly 50 individuals: Mind Reading [31], JeStimule [61], FaceSay2 [39], Emotion Trainer [66], Junior Detective program [9] and the Transporters [30]. All target emotion recognition or production.

We separated the serious games reported on here into 2 groups: those that mainly teach facial emotion recognition and production and those that teach social skills such as 
collaboration and adapting to environments. The work on facial emotions has been particularly investigated. The importance of emotion recognition in the cognitive impairments of individuals with autism is not consensual [39], although some authors consider emotion processing one of the major deficits in ASD [5]. Among the 16 games, 11 manipulated contextualized emotion. The aim is to promote functional generalisation to real life and help ASD individuals understand others' thoughts. However, it cannot be assumed that teaching an individual to recognize emotional facial expressions will be enough to foster her/his social skills in real life dynamic interactions. Unfortunately, we found very few games that offered training in producing emotions, particularly in social context $[26,51]$. The last point is the playful aspect of the games. Most games that train on facial emotions present a static environment that does not offer the player any possibility of interaction within the game. The majority use photographs and written sentences, and the player has to click on the mouse to select the correct answer. Some games attempt to be more fun with colours or drawings (e.g., FaceSay); their designs are warmer and more attractive. This can help players focus on the game but can also increase stimulation and distract them.

In contrast, serious games that train on collaborative or general social skills usually require greater player participation, unlike games that train on emotion recognition. In practice, half of the games training social skills are just a support for interactions between players. They do not work explicitly on social skills but train on them by constraining players to interact with their partners. These games do not train on one particular skill but rather require multiple players. The other half of the games is based on virtual environments that simulate real life. However, these games allow working only on few specific situations, and functional generalisation of behaviour may not be efficient, as social rules change with context. 
Some games, such as ECHOES [11], use gesture controls with sensors, for instance via RGB cameras; these require greater player participation. Other games, such as Junior Detective Agency, are based on realistic scenarios with story progressions; these computer interventions are closer to video games than scholarly exercises. According to the parents who participated in semi-structured interviews in the study by Abirached, Zhang \& Park [1], games of this type allow for deeper immersion and greater interest for children with ASD. This is also the rationale for games that use virtual reality environments that resemble real life [61]. Finally, it could be interesting to incorporate modules with cutting-edge technologies that support social skill improvement, such as joint attention or visual exploration [22], or that give feedback during the game by automatically extracting social signals.

A critical issue regarding the research in the field of ICT for ASD is whether the value added from ICT research also stems from the engineering systems that offer activities that would not otherwise be possible through therapist/patient education methods. A number of projects designed software that displayed pictures or photographs that could also be presented in a more classical format using a pen and pencil $[12,25,39,66]$. In addition, researchers should seek to exploit the full advantage of computing systems that can automatically respond to user input. Novel technologies enable the detection of subtle social non-verbal signals in a way that is much more difficult for therapists to achieve alone. For instance, gaze-contingent interfaces are used to capture users' gaze orientations in real time and provide them with feedback about their own gazes [33, 44, 67] Algorithms that detect facial expressions in real time are also currently being developed and tested in the serious game JeStimule for a second version of the game that offers feedback on the participants' emotion production (see: http://jemime.isir.upmc.fr/). The Autism Spectrum Condition-Inclusion (ASC-Inclusion) EU project aims to combine multiple state-of-the-art technologies in one software program that will analyse children's facial expressions, vocal intonations and gestures (using standard 
microphones and webcams); train children to recognise their own, and others' facial expressions, tones of voice and body gestures through interactive games, text communication, animations, and video and audio clips; personalise the settings according to children's individual needs; and support professionals, parents and caregivers with professional information, reports on the children's progress and forums to interact with other professionals and caregivers (see: http://asc-inclusion.eu/project/overview-2/).

\section{Conclusion}

The use of information communication technologies (ICTs) in therapy offers new perspectives for treating individuals with autism spectrum disorders (ASD) because they can be used in many different ways and settings and they are attractive to the patients. For training on social skills, serious games are very promising. They can be used to train many different skills and can favour interactions in diverse contexts and situations, some of which resemble real life. However, the currently available serious games present some limitations in terms of the evidence of their clinical benefits. It now appears necessary to measure the efficacy of ICTs and the use of serious games for remediation through more robust studies in terms of methodology (large samples, control groups, longer treatment periods, and follow-up to assess whether changes remain stable). We also need to pay more attention to game design and develop a specific framework for this type of serious game to propose games that challenge and engage the patients. Moreover, we still need to develop more serious games that are adapted to LF-ASD individuals and that are based on recent advances in computing systems that can automatically respond to user input. The current state-of-the-art has put much emphasis on the specific skills related to emotion recognition in faces. In the future, researchers should also promote other subsets of competencies that are essential to non-verbal social communication such as join attention or gestures. Features that characterize cognitive 
functioning in ASD should also be taken into account. Given that individuals with ASD are often reported to be visual thinkers [57], future studies ought to take full advantage the opportunities afforded by the visual representations inherent to serious games. 


\section{Bibliography}

1. Abirached, B., Zhang, Y., \& Park, J. H. (2012, June). Understanding User Needs for Serious Games for Teaching Children with Autism Spectrum Disorders Emotions. In World Conference on Educational Multimedia, Hypermedia and Telecommunications (Vol. 2012, No. 1, pp. 1054-1063).

2. Abirached, B., Zhang, Y., Aggarwal, J. K., Tamersoy, B., Fernandes, T., Miranda, J. C., \& Orvalho, V. (2011, November). Improving communication skills of children with ASDs through interaction with virtual characters. In Serious Games and Applications for Health (SeGAH), 2011 IEEE 1st International Conference on (pp. 1-4). IEEE.

3. Alves, S., Marques, A., Queirós, C., \& Orvalho, V. (2013). LIFEisGAME Prototype: A Serious Game about Emotions for Children with Autism Spectrum Disorders. PsychNology Journal, 11(3), 191-211.

4.Amiet, C., Gourfinkel-An, I., Laurent, C., Bodeau, N., Génin, B., Leguern, E., ... \& Cohen, D. (2013). Does epilepsy in multiplex autism pedigrees define a different subgroup in terms of clinical characteristics and genetic risk?. Molecular Autism, 4(1), 1.

5. Baron-Cohen, S. (1988). Social and pragmatic deficits in autism: cognitive or affective?. Journal of Autism and Developmental Disorders, $18(3), 379-402$.

6. Battocchi, A., Gal, E., Sasson, A. B., Pianesi, F., Venuti, P., Zancanaro, M., \& Weiss, P. L. (2008). Collaborative puzzle game-an interface for studying collaboration and social interaction for children who are typically developed or who have Autism Spectrum Disorder. 7th ICDVRAT with ArtAbilitation. ICDVRAT/University of Reading, UK, 127-134. 
7. Battocchi, A., Pianesi, F., Venuti, P., Ben-Sasson, A., Gal, E., \& Weiss, P. L. (2009, June). Collaborative puzzle game: Fostering collaboration in children with autistic spectrum disorder (ASD) and with typical development. In 2009 Virtual Rehabilitation International Conference. Haifa, Israel.

8. Battocchi, A., Pianesi, F., Tomasini, D., Zancanaro, M., Esposito, G., Venuti, P., ... \& Weiss, P. L. (2009, November). Collaborative Puzzle Game: a tabletop interactive game for fostering collaboration in children with Autism Spectrum Disorders (ASD). In Proceedings of the ACM International Conference on Interactive Tabletops and Surfaces (pp. 197-204). ACM. Canada.New-York ACM, 197-204.

9. Beaumont, R., \& Sofronoff, K. (2008). A multi - component social skills intervention for children with Asperger syndrome: The Junior Detective Training Program. Journal of Child Psychology and Psychiatry, 49(7), 743-753

10. Bernard-Opitz, V., Sriram, N., \& Nakhoda-Sapuan, S. (2001). Enhancing social problem solving in children with autism and normal children through computer-assisted instruction. Journal of Autism and Developmental Disorders, 31(4), 377-384.

11. Bernardini, S., Porayska-Pomsta, K., \& Smith, T. J. (2014). ECHOES: An intelligent serious game for fostering social communication in children with autism. Information Sciences, 264, 41-60.

12. Bölte, S., Hubl, D., Feineis-Matthews, S., Prvulovic, D., Dierks, T., \& Poustka, F. (2006). Facial affect recognition training in autism: can we animate the fusiform gyrus?. Behavioral Neuroscience, 120(1), 211. doi:10.1037/0735-7044.120.1.211 
13. Bono, V., Narzisi, A., Jouen, A.L., Tilmont, E., Hommel, S., Jamal, W. et al. (2016). GOLIAH: A gaming platform for home based intervention in Autism - principles and design. Frontiers in Psychiatry, 7, e70.

14. Boucenna, S., Narzisi, A., Tilmont, E., Muratori, F., Pioggia, G., Cohen, D., \& Chetouani, M. (2014). Interactive technologies for autistic children: A review. Cognitive Computation, 6(4), 722-740.

15. Chen, W. (2012). Multitouch tabletop technology for people with autism spectrum disorder: A review of the literature. Procedia Computer Science, 14, 198-207.

16. Cheng, Y., Chiang, H. C., Ye, J., \& Cheng, L. H. (2010). Enhancing empathy instruction using a collaborative virtual learning environment for children with autistic spectrum conditions. Computers \& Education, 55(4), 1449-1458.

17. Cheng, L., Kimberly, G., \& Orlich, F. (2002). KidTalk: online therapy for Asperger's syndrome. Microsoft Research.

18. Christinaki, E., Vidakis, N., \& Triantafyllidis, G. (2013, September). Facial expression recognition teaching to preschoolers with autism: a natural user interface approach. In Proceedings of the 6th Balkan Conference in Informatics (pp. 141-148). ACM. New-York, USA, 141-148.

19. Cockburn, J., Bartlett, M., Tanaka, J., Movellan, J., Pierce, M., \& Schultz, R. (2008). Smilemaze: A tutoring system in real-time facial expression perception and production in children with autism spectrum disorder. In ECAG 2008 Workshop Facial and Bodily Expressions for Control and Adaptation of Games (p. 3). Amsterdam. 
20. Connolly, T. M., Boyle, E. A., MacArthur, E., Hainey, T., \& Boyle, J. M. (2012). A systematic literature review of empirical evidence on computer games and serious games. Computers \& Education, 59(2), 661-686.

21. Marfisi-Schottman, I., George, S., \& Tarpin-Bernard, F. (2010, October). Tools and methods for efficiently designing serious games. In 4th European Conference on Games Based Learning ECGBL2010 (pp. 226-234). Aarhus University, Denmark.

22. Courgeon, M., Rautureau, G., Martin, J. C., \& Grynszpan, O. (2014). Joint attention simulation using eye-tracking and virtual humans. Affective Computing, IEEE Transactions on, 5(3), 238-250. doi:10.1109/TAFFC.2014.2335740

23. Diehl, J. J., Schmitt, L. M., Villano, M., \& Crowell, C. R. (2012). The clinical use of robots for individuals with autism spectrum disorders: A critical review. Research in Autism Spectrum Disorders, 6(1), 249-262.

24. Durkin, K. (2010). Videogames and young people with developmental disorders. Review of General Psychology, $14(2), 122$.

25. Faja, S., Aylward, E., Bernier, R., \& Dawson, G. (2007). Becoming a face expert: A computerized face-training program for high-functioning individuals with autism spectrum disorders. Developmental Neuropsychology, 33(1), 1-24. doi:10.1080/87565640701729573

26. Fernandes, T., Alves, S., Miranda, J., Queirós, C., \& Orvalho, V. (2011). LIFEisGAME: A facial character animation system to help recognize facial expressions. In Enterprise Information Systems (pp. 423-432). Springer Berlin Heidelberg.

27. Finkelstein, S. L., Nickel, A., Harrison, L., Suma, E. A., \& Barnes, T. (2009, March). cMotion: A new game design to teach emotion recognition and programming logic to children using virtual humans. In Virtual Reality Conference, 2009. VR 2009. IEEE (pp. 249-250). IEEE. 
28. Giusti, L., Zancanaro, M., Gal, E., \& Weiss, P. L. T. (2011, May). Dimensions of collaboration on a tabletop interface for children with autism spectrum disorder. In Proceedings of the SIGCHI Conference on Human Factors in Computing Systems (pp. 3295-3304). ACM. New York, New York.

29. Gal, E., Bauminger, N., Goren-Bar, D., Pianesi, F., Stock, O., Zancanaro, M., \& Weiss, P. L. T. (2009). Enhancing social communication of children with high-functioning autism through a co-located interface. Ai \& Society, 24(1), 75-84.

30. Golan, O., Ashwin, E., Granader, Y., McClintock, S., Day, K., Leggett, V., \& Baron-Cohen, S. (2010). Enhancing emotion recognition in children with autism spectrum conditions: An intervention using animated vehicles with real emotional faces. Journal of Autism and Developmental Disorders, 40(3), 269-279.

31. Golan, O., \& Baron-Cohen, S. (2006). Systemizing empathy: Teaching adults with Asperger syndrome or high-functioning autism to recognize complex emotions using interactive multimedia. Development and Psychopathology, 18(2), 591.

32. Goldsmith, T. R., \& LeBlanc, L. A. (2004). Use of technology in interventions for children with autism. Journal of Early and Intensive Behavior Intervention, 1(2), 166.

33. Grynszpan, O., Nadel, J., Martin, J. C., Simonin, J., Bailleul, P., Wang, Y., ... \& Constant, J. (2012). Self-monitoring of gaze in high functioning autism. Journal of Autism and Developmental Disorders, 42(8), 1642-1650. doi:10.1007/s10803-011-1404-9 
34. Grynszpan, O., Weiss, P. L. T., Perez-Diaz, F., \& Gal, E. (2014). Innovative technology-based interventions for autism spectrum disorders: A meta-analysis. Autism, 18(4), 346-361.

35. Harrold, N., Tan, C. T., Rosser, D., \& Leong, T. W. (2014, April). CopyMe: an emotional development game for children. In CHI'14 Extended Abstracts on Human Factors in Computing Systems (pp. 503-506). ACM.

36. Harrold, N., Tan, C. T., Rosser, D., \& Leong, T. W. (2014, April). CopyMe: a portable real-time feedback expression recognition game for children. In CHI'14 Extended Abstracts on Human Factors in Computing Systems (pp. 1195-1200). ACM.

37. Hopkins, I. M., Gower, M. W., Perez, T. A., Smith, D. S., Amthor, F. R., Wimsatt, F. C., \& Biasini, F. J. (2011). Avatar assistant: improving social skills in students with an ASD through a computer-based intervention. Journal of Autism and Developmental Disorders, 41(11), 15431555 .

38. Huijnen, C. A., Lexis, M. A., Jansens, R., \& Witte, L. P. (2016). Mapping Robots to Therapy and Educational Objectives for Children with Autism Spectrum Disorder. Journal of autism and developmental disorders, 46(6), 2100-2114.

39. Jones, C. R., Pickles, A., Falcaro, M., Marsden, A. J., Happé, F., Scott, S. K., ... \& Simonoff, E. (2011). A multimodal approach to emotion recognition ability in autism spectrum disorders. Journal of Child Psychology and Psychiatry, 52(3), 275-285.

40. Josman, N., Ben-Chaim, H. M., Friedrich, S., \& Weiss, P. L. (2008). Effectiveness of virtual reality for teaching street-crossing skills to children and adolescents with autism. International Journal on Disability and Human Development, 7(1), 49-56. 
41. Kagohara, D. M., van der Meer, L., Ramdoss, S., O’Reilly, M. F., Lancioni, G. E., Davis, T. N., ... \& Green, V. A. (2013). Using iPods® and iPads $®$ in teaching programs for individuals with developmental disabilities: A systematic review. Research in Developmental Disabilities, $34(1), 147-156$.

42. Kandalaft, M. R., Didehbani, N., Krawczyk, D. C., Allen, T. T., \& Chapman, S. B. (2013). Virtual reality social cognition training for young adults with high-functioning autism. Journal of Autism and Developmental Disorders, 43(1), 34-44.

43. Khowaja, K., Salim, S.S. (2014, May). Design Components for Serious Games of Children with Autism Spectrum Disorder (ASD). In International Symposium on Simulation and Serious Games 2014. Kintex Convention Center, South Korea. doi: 10.3850/978-981-09-04630_061

44. Lahiri, U., Bekele, E., Dohrmann, E., Warren, Z., \& Sarkar, N. (2013). Design of a virtual reality based adaptive response technology for children with autism. Neural Systems and Rehabilitation Engineering, IEEE Transactions on, 21(1), 55-64. doi:10.1109/TNSRE.2012.2218618

45. Lozano-Martínez, J., Ballesta-Pagán, F. J., \& Alcaraz-García, S. (2011). Software for Teaching Emotions to Students with Autism Spectrum Disorder. Revista Comunicar, 18(36), 139-148.

46. Marne, B., Wisdom, J., Huynh-Kim-Bang, B., \& Labat, J. M. (2012). The six facets of serious game design: a methodology enhanced by our design pattern library. In 21st Century Learning for 21 st Century Skills (pp. 208-221). Springer Berlin Heidelberg.

47. Marwecki, S., Rädle, R., \& Reiterer, H. (2013). Encouraging collaboration in hybrid therapy games for autistic children (pp. 469-474). ACM. 
48. Mitchell, P., Parsons, S., \& Leonard, A. (2007). Using virtual environments for teaching social understanding to 6 adolescents with autistic spectrum disorders. Journal of Autism and Developmental Disorders, 37(3), 589-600.

49. Noor, H. A. M., Shahbodin, F., \& Pee, N. C. (2012). Serious game for autism children: review of literature. World Academy of Science, Engineering and Technology, International Journal of Social, Behavioral, Educational, Economic, Business and Industrial Engineering, 6(4), 554-559.

50. Odom, S. L., Thompson, J. L., Hedges, S., Boyd, B. A., Dykstra, J. R., Duda, M. A., ... \& Bord, A. (2015). Technology-aided interventions and instruction for adolescents with autism spectrum disorder. Journal of Autism and Developmental Disorders, 45(12), 3805-3819.

51. Park, J. H., Abirached, B., \& Zhang, Y. (2012, May). A framework for designing assistive technologies for teaching children with ASDs emotions. In CHI'12 Extended Abstracts on Human Factors in Computing Systems (pp. 2423-2428). ACM. New-York, New York

52. Parsons, S., Leonard, A., \& Mitchell, P. (2006). Virtual environments for social skills training: comments from two adolescents with autistic spectrum disorder. Computers \& Education, 47(2), 186-206.

53. Parsons, S., Mitchell, P., \& Leonard, A. (2004). The use and understanding of virtual environments by adolescents with autistic spectrum disorders. Journal of Autism and Developmental Disorders, 34(4), 449-466.

54. Piper, A. M., O'Brien, E., Morris, M. R., \& Winograd, T. (2006, November). SIDES: a cooperative tabletop computer game for social skills development. In Proceedings of the 2006 20th anniversary conference on Computer supported cooperative work (pp. 1-10). ACM. 
55. Ploog, B. O., Scharf, A., Nelson, D., \& Brooks, P. J. (2013). Use of computer-assisted technologies (CAT) to enhance social, communicative, and language development in children with autism spectrum disorders. Journal of Autism and Developmental Disorders, 43(2), $301-322$.

56. Queirós, C., Alves, S., Marques, A. J., Oliveira, M., \& Orvalho, V. (2012). Serious games and emotion teaching in autism spectrum disorders: a comparison with LIFEisGAME project. At :

https://www.google.com/url?q=http://sigarra.up.pt/fpceup/pt/publs_pesquisa.show_publ_file\%3Fpct_gdoc_id\%3D39614\&sa=U\&ei=oju1VJH4K oHBUoPLgvgK\&ved=0CAkQFjADOAo\&client=internal-uds-cse\&usg=AFQjCNGc4EgJ2tkb-swAkPukPUj739TIiw. Accessed 13 January 2015

57. Quill, K. A. (1997). Instructional considerations for young children with autism: The rationale for visually cued instruction. Journal of Autism and Developmental Disorders, 27(6), 697-714.

58. Ramdoss, S., Machalicek, W., Rispoli, M., Mulloy, A., Lang, R., \& O’Reilly, M. (2012). Computer-based interventions to improve social and emotional skills in individuals with autism spectrum disorders: A systematic review. Developmental Neurorehabilitation, 15(2), 119-135.

59. Scassellati, B. (2007). How social robots will help us to diagnose, treat, and understand autism. In Robotics Research (pp. 552-563). Springer Berlin Heidelberg.

60. Scottish Intercollegiate Guidelines Network (SIGN) Network, S. I. G. (2006). Assessment, diagnosis and clinical interventions for children and young people with autism spectrum disorders. 
61. Serret, S., Hun, S., Iakimova, G., Lozada, J., Anastassova, M., Santos, A., ... \& Askenazy, F. (2014). Facing the challenge of teaching emotions to individuals with low-and high-functioning autism using a new Serious game: a pilot study. Molecular Autism, 5(1), 1.

62. Silva, G. F. M., Raposo, A., \& Suplino, M. (2014). Par: A collaborative game for multitouch tabletop to support social interaction of users with autism. Procedia Computer Science, 27, 84-93.

63. Silver, M., \& Oakes, P. (2001). Evaluation of a new computer intervention to teach people with autism or Asperger syndrome to recognize and predict emotions in others. Autism, 5(3), 299-316.

64. Spence, S. H. (2003). Social skills training with children and young people: Theory, evidence and practice. Child and Adolescent Mental Health, 8(2), 84-96.

65. Tan, C. T., Harrold, N., \& Rosser, D. (2013, November). Can you CopyMe?: an expression mimicking serious game. In SIGGRAPH Asia 2013 Symposium on Mobile Graphics and Interactive Applications (p. 73). ACM. New York, New York.

66. Tanaka, J. W., Wolf, J. M., Klaiman, C., Koenig, K., Cockburn, J., Herlihy, L., ... \& Schultz, R. T. (2010). Using computerized games to teach face recognition skills to children with autism spectrum disorder: The Let's Face It! program. Journal of Child Psychology and Psychiatry, 51(8), 944-952. doi:10.1111/j.1469-7610.2010.02258.x

67. Trepagnier, C. Y., Sebrechts, M. M., Finkelmeyer, A., Stewart, W., Woodford, J., \& Coleman, M. (2006). Simulating social interaction to address deficits of autistic spectrum disorder in children. Cyberpsychology \& Behavior, 9(2), 213-217. doi:10.1089/cpb.2006.9.213 
68. Van Veen, M., de Vries, A., Cnossen, F., \& Willems, R. (2009). Improving collaboration skills for children with PDD-NOS through a multitouch based serious game. In Proc. of international conference of Education and New Learning Technologies (pp. 3559-3570).

69. Vannetzel, L., Chaby, L., Cautru, F., Cohen, D., \& Plaza, M. (2011). Neutral versus emotional human stimuli processing in children with pervasive developmental disorders not otherwise specified. Research in Autism Spectrum Disorders, 5(2), 775-783.

70. Wainer, A. L., \& Ingersoll, B. R. (2011). The use of innovative computer technology for teaching social communication to individuals with autism spectrum disorders. Research in Autism Spectrum Disorders, 5(1), 96-107.

71. Whalen, C., Moss, D., Ilan, A. B., Vaupel, M., Fielding, P., Macdonald, K., ... \& Symon, J. (2010). Efficacy of TeachTown: Basics computer-assisted intervention for the intensive comprehensive autism program in Los Angeles unified school district. Autism, 14(3), 179-197.

72. Whyte, E. M., Smyth, J. M., \& Scherf, K. S. (2015). Designing serious game interventions for individuals with autism. Journal of Autism and Developmental Disorders, 45(12), 3820-3831.

73. Young, R. L., \& Posselt, M. (2012). Using the transporters DVD as a learning tool for children with autism spectrum disorders (ASD). Journal of autism and developmental disorders, 42(6), 984-991.

74. Yusoff, A. (2010). A conceptual framework for serious games and its validation (Doctoral dissertation, University of Southampton) Available: http://eprints.soton.ac.uk/171663/1.hasCoversheetVersion/Thesis_017b.pdf 
75. Zarin, R., \& Fallman, D. (2011, May). Through the troll forest: exploring tabletop interaction design for children with special cognitive needs. In Proceedings of the SIGCHI Conference on Human Factors in Computing Systems (pp. 3319-3322). ACM. New York, New York 


\section{FIGURE CAPTION}

Figure 1. Flow diagram of the search method used in this study

Figure 2. Number of publications describing serious games to train social interaction and emotion to people with autism spectrum disorder, according to the year of publication

Figure 3. Clinical validity and game playability/design as evidenced by the Connolly and Yusoff scale scores, respectively, in all games training social interaction and emotions to people with autism spectrum disorder (ASD) 


\section{Table 1: Definition of the attributes used in the Yusoff scale}

\begin{tabular}{|c|c|}
\hline Attributes & Definition \\
\hline Incremental Learning & Tutorial, examples and presentation of material and exercises \\
\hline Linearity & Logical sequence of exercises and a steadily increasing difficulty level \\
\hline Attention span & Taking into account the capacity of attention and adapted duration of exercises \\
\hline Scaffolding & $\begin{array}{l}\text { Average used to help the patient comprehend and progress in the game, such as } \\
\text { visual support }\end{array}$ \\
\hline Transfer of learned skills & Reuse of the learned skills in other exercises \\
\hline Interaction & $\begin{array}{l}\text { A way to allow the player to stay interested and engaged in the game. The game } \\
\text { must be challenging and fun. }\end{array}$ \\
\hline Learner control & $\begin{array}{l}\text { Possibility for the player (or the supervisor) to control different functions in the } \\
\text { game, such as the duration, order of the exercises, and development. }\end{array}$ \\
\hline Practice and drill & Using new skills repetitively to ensure the acquisition of the skills \\
\hline Intermittent feedback & Feedback during the exercises, such as points won or auditory feedback. \\
\hline Reward & A reward upon the completion of an exercise is given \\
\hline $\begin{array}{l}\text { Situated and authentic } \\
\text { learning }\end{array}$ & Work with context \\
\hline Accommodating the learner & Possibility for the player to personalize or adapt the game to his/her tastes \\
\hline
\end{tabular}


Table 2: Serious games that target emotion recognition or production $(\mathrm{N}=16)$ in individuals with autism spectrum disorder

\begin{tabular}{|c|c|c|c|c|c|c|c|}
\hline $\begin{array}{l}\text { Project } \\
\text { (Study } \\
\text { publication) } \\
\end{array}$ & $\begin{array}{l}\text { Targeted } \\
\text { participants }\end{array}$ & Targeted skills & Support & Clinical study & Main results & Models and comments & $\begin{array}{l}\text { Connolly } \\
\text { scale score }\end{array}$ \\
\hline $\begin{array}{l}\text { Aprende con } \\
\text { zapo } \\
\text { (Lozano et al., } \\
\text { 2011) [45] }\end{array}$ & $\begin{array}{l}\text { Children with } \\
\text { ASD ( } 8 \text { to } 18 \\
\text { years), able to } \\
\text { read }\end{array}$ & $\begin{array}{l}\text { Facial recognition } \\
\text { with and without } \\
\text { context and theory } \\
\text { of mind }\end{array}$ & $\begin{array}{l}\text { Drawings } \\
\text { and photos }\end{array}$ & $\begin{array}{l}\text { Open pilot study of } \\
9 \text { children aged } 8 \text { to } 18 \\
\text { years, with a } \\
\text { developmental age from } \\
5 \text { to } 7 \text {, for } \\
45 \text { min per week over } 20 \\
\text { weeks. }\end{array}$ & $\begin{array}{l}\text { Pre-test and post-test of } \\
\text { emotional skills (no } \\
\text { information on the test): } \\
\text { all children show better } \\
\text { results for emotion } \\
\text { recognition and } \\
\text { prediction of people's } \\
\text { actions from their true or } \\
\text { false beliefs. }\end{array}$ & $\begin{array}{l}\text { Theory of mind } \\
\text { Redundant character (Clown } \\
\text { Zappo) }\end{array}$ & 7 \\
\hline $\begin{array}{l}\text { CMotion } \\
\text { (Finkelstein et } \\
\text { al., 2009) [27] }\end{array}$ & $\begin{array}{l}\text { Individuals } \\
\text { with HF-ASD }\end{array}$ & $\begin{array}{l}\text { Recognise facial } \\
\text { expressions and } \\
\text { emotions in } \\
\text { context }\end{array}$ & $\begin{array}{l}\text { Virtual } \\
\text { moving } \\
\text { characters } \\
\text { in 3D }\end{array}$ & No & No & $\begin{array}{l}\text { Culturally situated design } \\
\text { tools } \\
\text { Fun design }\end{array}$ & 6 \\
\hline $\begin{array}{l}\text { CopyMe } \\
\text { (Tan et al., } \\
\text { 2013) [65] } \\
\text { (Harrold et al., } \\
\text { 2014a) [35] } \\
\text { (Harrold et al., } \\
\text { 2014b) [36] }\end{array}$ & $\begin{array}{l}\text { Children with } \\
\text { ASD }\end{array}$ & $\begin{array}{l}\text { Mimicking facial } \\
\text { expressions from a } \\
\text { model }\end{array}$ & $\begin{array}{l}\text { Pictures of } \\
\text { real persons }\end{array}$ & $\begin{array}{l}\text { The game was used with } \\
\text { children aged } 8 \text { to } 10 \\
\text { years in a childcare centre } \\
\text { in Sydney. However, no } \\
\text { assessment was reported. }\end{array}$ & No & $\begin{array}{l}\text { Deformable model fitting } \\
\text { (Saraghi et al, 2010) with } \\
\text { ofx FaceTracker add-on in } \\
\text { the OpenFrameworks C++ } \\
\text { toolkit using the OpenCV } \\
\text { Library. } \\
\text { Visual feedback in real time. } \\
\text { The design did not involve } \\
\text { an autism professional. } \\
\text { An online questionnaire is } \\
\text { available for caregivers to } \\
\text { judge the game }\end{array}$ & 5 \\
\hline $\begin{array}{l}\text { Computer-based } \\
\text { program } \\
\text { (Bölte et al., } \\
\text { 2002) [12] }\end{array}$ & $\begin{array}{l}\text { Adolescents } \\
\text { and adults } \\
\text { with HF-ASD } \\
\text { or AS }\end{array}$ & $\begin{array}{l}\text { Identify basic } \\
\text { facial emotions }\end{array}$ & Photos & $\begin{array}{l}\text { Open pilot study of } \\
10 \text { adolescents with HF- } \\
\text { ASD or AS, } \\
5 \text { of which were randomly } \\
\text { assigned to receive } 2 \\
\text { hours training per week } \\
\text { for } 5 \text { weeks. The others } \\
\text { served as controls }\end{array}$ & $\begin{array}{l}\text { Improved post-test } \\
\text { measures related to } \\
\text { training (facial emotion } \\
\text { recognition). No } \\
\text { generalisation based on } \\
\text { the International } \\
\text { Affective Pictures } \\
\text { System. }\end{array}$ & $\begin{array}{l}\text { Theory of mind } \\
\text { Executive dysfunction } \\
\text { Weak central coherence } \\
\text { Feedback in function of the } \\
\text { answer }\end{array}$ & 9 \\
\hline
\end{tabular}




\begin{tabular}{|c|c|c|c|c|c|c|c|}
\hline $\begin{array}{l}\text { The Junior } \\
\text { Detective } \\
\text { Training } \\
\text { Program } \\
\text { (Beaumont et al, } \\
\text { 2008) [9] }\end{array}$ & $\begin{array}{l}\text { Children with } \\
\text { AS } \\
\text { ( } 7.5 \text { to } 12 \\
\text { years) }\end{array}$ & $\begin{array}{l}\text { Emotion } \\
\text { recognition and } \\
\text { social skills in } \\
\text { context }\end{array}$ & $\begin{array}{l}\text { Game in 3D } \\
\text { with real } \\
\text { scenarios }\end{array}$ & $\begin{array}{l}\text { Randomised controlled } \\
\text { study } \\
\mathrm{N}=49 \\
26 \text { were randomly } \\
\text { assigned to intervention, } \\
23 \text { controls. Groups were } \\
\text { matched on age, IQ, and } \\
\text { social competences } \\
\text { (measured by the Social } \\
\text { Skills Questionnaire). } \\
7 \text { sessions (1 per week) } \\
\text { with game time and group } \\
\text { therapy }\end{array}$ & $\begin{array}{l}\text { Significant improvement } \\
\text { in the intervention group } \\
\text { for social skills (based } \\
\text { on SSQ and ERSSQ) } \\
\text { and emotion } \\
\text { management. } \\
\text { Significant improvement } \\
\text { in emotion recognition } \\
\text { for both groups. } \\
\text { A significant } \\
\text { improvement in social } \\
\text { skills at the } 5 \text { month } \\
\text { follow-up. }\end{array}$ & $\begin{array}{l}\text { http://www.sst- } \\
\text { institute.net/au/professionals/ } \\
\text { computer-game-workshop } \\
\text { Fun design }\end{array}$ & 12 \\
\hline $\begin{array}{l}\text { Emotion Trainer } \\
\text { (Silver \& Oakes, } \\
\text { 2001) [63] }\end{array}$ & $\begin{array}{l}\text { Individuals } \\
\text { with AS }\end{array}$ & $\begin{array}{l}\text { Recognise and } \\
\text { predict emotions } \\
\text { with and without } \\
\text { context }\end{array}$ & Photos & $\begin{array}{l}\text { Nonrandomised } \\
\text { controlled study } \\
11 \text { AS between } 10 \text { to } 18 \\
\text { years. } \\
\geq 7 \text { years developmental } \\
\text { age. } 11 \text { AS controls } \\
\text { matched for age and } \\
\text { gender } \\
10 \text { sessions of } 30 \text { minutes } \\
\text { during } 3 \text { weeks }\end{array}$ & $\begin{array}{l}\text { Significant improvement } \\
\text { for the treatment group } \\
\text { in cartoon emotion } \\
\text { recognition and theory } \\
\text { of mind. No significant } \\
\text { difference in emotion } \\
\text { recognition between } \\
\text { groups. }\end{array}$ & Theory of mind & 12 \\
\hline $\begin{array}{l}\text { Facial } \\
\text { expression } \\
\text { recognition } \\
\text { serious game } \\
\text { (Christinaki et } \\
\text { al., 2013) [18] } \\
\end{array}$ & $\begin{array}{l}\text { Pre-schoolers } \\
\text { with ASD } \\
\text { ( } 2 \text { to } 6 \text { years) }\end{array}$ & $\begin{array}{l}\text { Recognise basic } \\
\text { emotions with and } \\
\text { without context }\end{array}$ & Photos & & No & $\begin{array}{l}\text { Piaget's model } \\
\text { Kolb's experiential learning } \\
\text { theory } \\
\text { Gestural control by Kinect }\end{array}$ & 6 \\
\hline $\begin{array}{l}\text { FaceSay2 } \\
\text { (Hopkins et al., } \\
\text { 2011) [37] }\end{array}$ & $\begin{array}{l}\text { Children and } \\
\text { adolescents } \\
\text { with LF- and } \\
\text { HF-ASD }\end{array}$ & $\begin{array}{l}\text { Discriminate and } \\
\text { recognise facial } \\
\text { expressions and } \\
\text { joint attention }\end{array}$ & $\begin{array}{l}\text { Photos and } \\
\text { drawings }\end{array}$ & $\begin{array}{l}\text { Randomised controlled } \\
\text { study } \\
49 \text { participants (25 LF- } \\
\text { ASD, } 24 \text { HF-ASD) aged } 6 \\
\text { to } 15 \text { years. } \\
\text { Developmental age from } \\
6 \text { to } 10 \text { years } \\
11 \mathrm{LF} \text { and } 13 \mathrm{HF} \text { trained } \\
2 \text { times a week during } 6 \\
\text { weeks. Session duration: }\end{array}$ & $\begin{array}{l}\text { Significant improvement } \\
\text { in emotion recognition } \\
\text { for the individuals with } \\
\text { HF-ASD in the } \\
\text { treatment group. The } \\
\text { improvement in emotion } \\
\text { recognition for the } \\
\text { individuals with LF- } \\
\text { ASD in the treatment } \\
\text { group was not shown for }\end{array}$ & & 14 \\
\hline
\end{tabular}




\begin{tabular}{|c|c|c|c|c|c|c|c|}
\hline & & & & $\begin{array}{l}10 \text { to } 25 \mathrm{~min} \\
\text { The control group (14 LF } \\
\text { and } 11 \mathrm{HF} \text { ) used Tux } \\
\text { Paint during their } \\
\text { sessions. }\end{array}$ & $\begin{array}{l}\text { all tests. } \\
\text { The quality of } \\
\text { interaction after } \\
\text { treatment is better for } \\
\text { the treatment group than } \\
\text { the control group. }\end{array}$ & & \\
\hline $\begin{array}{l}\text { JeStimule } \\
\text { (Serret and al., } \\
\text { 2014) [61] }\end{array}$ & $\begin{array}{l}\text { Individuals } \\
\text { with LF and } \\
\text { HF ASD }\end{array}$ & $\begin{array}{l}\text { Recognise } \\
\text { emotions without } \\
\text { or with context }\end{array}$ & $\begin{array}{l}\text { Serious } \\
\text { game in 3D } \\
\text { with real } \\
\text { scenarios } \\
\text { and avatars }\end{array}$ & $\begin{array}{l}\text { Stratified open trial on } \\
33 \text { patients with ASD } \\
\text { aged } 6 \text { to } 18 \text { years } \\
\text { Stratified for age and } \\
\text { developmental age } \\
\text { Trained } 2 \text { times a week } \\
\text { for } 4 \text { weeks. } \\
\text { Session duration: } 1 \text { hour }\end{array}$ & $\begin{array}{l}\text { Descriptive data showed } \\
\text { suitable adaptability. } \\
\text { Significant effect for } \\
\text { session on avatars and } \\
\text { on pictures of real-life } \\
\text { characters. } \\
\text { Significant effect for } \\
\text { session } \times \text { task } \times \text { emotion } \\
\text { interaction for avatars } \\
\text { and near significance for } \\
\text { pictures of real-life } \\
\text { characters. }\end{array}$ & $\begin{array}{l}\text { Play with the mouse or } \\
\text { Joystick }\end{array}$ & 12 \\
\hline $\begin{array}{l}\text { Let's face it } \\
\text { (Tanaka et al., } \\
2010) \\
{[66]}\end{array}$ & $\begin{array}{l}\text { Children, } \\
\text { adolescents } \\
\text { and young } \\
\text { adults with } \\
\text { ASD and AS }\end{array}$ & Face recognition & Photos & $\begin{array}{l}\text { Randomised controlled } \\
\text { study } \\
42 \text { participants (mean } \\
\text { IQ=93.6) played during } \\
20 \text { hours } \\
37 \text { controls with ASD } \\
\text { (mean } \mathrm{IQ}=95.9 \text { ) }\end{array}$ & $\begin{array}{l}\text { The Let's Face It skills } \\
\text { battery was used to } \\
\text { assess social skills pre- } \\
\text { and post-treatment. The } \\
\text { authors found no } \\
\text { significant differences } \\
\text { for most of the subtests. } \\
\text { Only the subtest } \\
\text { Part/Whole identity } \\
\text { showed significantly } \\
\text { better results in attention } \\
\text { to eyes and mouth for } \\
\text { the treatment group } \\
\text { compared to the control } \\
\text { group after the training } \\
\text { sessions }\end{array}$ & $\begin{array}{l}\text { Hierarchical face processing } \\
\text { model (Tanaka et al., 2003) } \\
\text { Participants were not } \\
\text { included if the clinician } \\
\text { thought they would not } \\
\text { understand the instructions. }\end{array}$ & 13 \\
\hline $\begin{array}{l}\text { LifeIsGame } \\
\text { (Fernandes et } \\
\text { al., 2011) [26] } \\
\text { (Abirached et } \\
\text { al., 2011) [2] }\end{array}$ & $\begin{array}{l}\text { Individuals } \\
\text { with LF and } \\
\text { HF autism }\end{array}$ & $\begin{array}{l}\text { Recognise and } \\
\text { produce facial } \\
\text { emotions with and } \\
\text { without context }\end{array}$ & $\begin{array}{l}\text { Cartoon } \\
\text { with avatar } \\
\text { in 3D } \\
\text { On } \\
\text { computer }\end{array}$ & $\begin{array}{l}\text { Only a qualitative } \\
\text { assessment of the design } \\
\text { by } 9 \text { participants. } \\
\text { No evaluation. }\end{array}$ & $\begin{array}{l}\text { Participants enjoyed } \\
\text { playing this game. } \\
\text { The children seemed to } \\
\text { match images more than } \\
\text { they recognised }\end{array}$ & $\begin{array}{l}4 \text { game modes } \\
\text { Real-time automatic facial } \\
\text { analysis => Active } \\
\text { Appearance Model } \\
\text { Positive and negative }\end{array}$ & 6 \\
\hline
\end{tabular}


LifeIsGame

(Alves et al

2013) [3]

\begin{tabular}{|c|c|c|c|}
\hline $\begin{array}{l}\text { Mind Reading } \\
\text { (Golan et } \\
\text { Baron-Cohen, } \\
\text { 2006) [31] }\end{array}$ & $\begin{array}{l}\text { Individuals } \\
\text { with AS or } \\
\text { HF-ASD }\end{array}$ & $\begin{array}{l}\text { Recognise emotion } \\
\text { from faces and } \\
\text { voices, with and } \\
\text { without context }\end{array}$ & $\begin{array}{l}\text { Films, } \\
\text { recordings } \\
\text { and written } \\
\text { examples of } \\
\text { situations }\end{array}$ \\
\hline
\end{tabular}

Pilot study

11 children tested the

game once for $15 \mathrm{~min}$.

Parents and professional opinions collected

Controlled study

with AS or in the participants

pitities to recognise

controls with AS or HF- complex emotions from

ASD and 24 children with voices and faces

typical development.

Training from 10 to 15

weeks.

Experiment 2

13 participants with AS or

HF-ASD used Mind

Reading alone $2 \mathrm{hr} /$ week

for 10 weeks and in small

groups with a tutor 1

time/week for 10 weeks.

13 participants in the

control group took part in

10 sessions of social skills training.

13 typical participants

were matched to

experimental and control

groups.

compared with their

performance before

training and the control

group's performance.

Improvement was

limited to close but not

distant generalisation

tasks.

Experiment 2:

in the participants'

abilities to recognise

complex emotions from

voices and faces

compared with their

training and the control

group's performance.
Good comprehension of 5 game modes

the game and ease of use Positive feedback

with the iPad

Experiment 1:
Significant improvement

performance before

Improvement was

limited to close but not

distant generalisation

tasks. 


\begin{tabular}{|c|c|c|c|c|c|c|c|}
\hline $\begin{array}{l}\text { SmileMaze } \\
\text { (Cockburn et } \\
\text { al ., 2008) [19] }\end{array}$ & $\begin{array}{l}\text { Children with } \\
\text { ASD }\end{array}$ & $\begin{array}{l}\text { Recognition and } \\
\text { production of } \\
\text { facial emotions }\end{array}$ & Smileys & No & $\begin{array}{l}\text { Informal field-testing } \\
\text { showed that children } \\
\text { with ASD enjoy playing } \\
\text { the game. }\end{array}$ & $\begin{array}{l}\text { Computer Expression } \\
\text { Recognition Toolbox } \\
\text { Players need to mimic an } \\
\text { emotion to progress through } \\
\text { a maze. }\end{array}$ & 5 \\
\hline $\begin{array}{l}\text { Theory driven } \\
\text { serious game } \\
\text { framework } \\
\text { (Park et al., } \\
\text { 2012) [51] }\end{array}$ & $\begin{array}{l}\text { Individuals } \\
\text { with ASD able } \\
\text { to read }\end{array}$ & $\begin{array}{l}\text { Recognise and } \\
\text { produce emotions } \\
\text { with and without } \\
\text { context }\end{array}$ & $\begin{array}{l}\text { Photos and } \\
\text { writings }\end{array}$ & 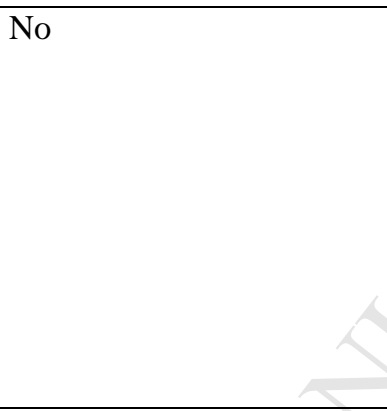 & No & $\begin{array}{l}\text { Piaget's model } \\
\text { Kolb's experiential learning } \\
\text { theory } \\
6 \text { levels: recognising, } \\
\text { matching, observing, } \\
\text { understanding, generalising, } \\
\text { mimicking } \\
\text { An ASD professional was } \\
\text { not involved in the game } \\
\text { design. }\end{array}$ & 6 \\
\hline $\begin{array}{l}\text { The transporters } \\
\text { (Golan et al., } \\
\text { 2010) [30] }\end{array}$ & $\begin{array}{l}\text { Children with } \\
\text { HF- and LF- } \\
\text { ASD } \\
\text { ( } 3 \text { to } 8 \text { years) }\end{array}$ & $\begin{array}{l}\text { Emotion } \\
\text { comprehension in } \\
\text { context }\end{array}$ & $\begin{array}{l}\text { Series of } \\
\text { 3D video } \\
\text { animations }\end{array}$ & $\begin{array}{l}\text { Controlled study } \\
20 \text { children with ASD ( } 4 \\
\text { to } 7 \text { years) and } 2 \text { matched } \\
\text { control groups: } 18 \\
\text { children with ASD and } 18 \\
\text { children with typical } \\
\text { development. } \\
\text { The exposed children } \\
\text { watched at least } 3 \\
\text { episodes every day for } 4 \\
\text { weeks. }\end{array}$ & $\begin{array}{l}\text { Significant improvement } \\
\text { in the results for familiar } \\
\text { close generalisation, } \\
\text { unfamiliar close } \\
\text { generalisation, and } \\
\text { distant generalisation } \\
\text { tasks. } \\
\text { The results for the } \\
\text { experimental group were } \\
\text { identical to those for the } \\
\text { control groups. } \\
\text { After training, the } \\
\text { results from the } \\
\text { experimental group were } \\
\text { the same as those from } \\
\text { the typical children. }\end{array}$ & $\begin{array}{l}\text { Empathising-Systemising } \\
\text { theory } \\
\text { One episode of } 5 \text { minutes per } \\
\text { emotion ( } 15 \text { emotions). } \\
\text { Watch a video and then } \\
\text { respond to a quiz (matching } \\
\text { faces to faces, emotions, and } \\
\text { situations). } \\
\text { The number of episodes } \\
\text { watched varied widely } \\
\text { between participants. }\end{array}$ & 14 \\
\hline $\begin{array}{l}\text { (Young \& } \\
\text { Posselt, 2012) } \\
{[73]}\end{array}$ & & & & $\begin{array}{l}\text { Randomised control study } \\
13 \text { participants with ASD } \\
\text { and } 12 \text { controls with ASD } \\
\text { between } 4 \text { and } 8 \text { years. } \\
\text { The controls watched a } \\
\text { "Thomas, the Tank }\end{array}$ & $\begin{array}{l}\text { Significant improvement } \\
\text { in emotion recognition } \\
\text { for the participants, but } \\
\text { not for the controls. } \\
\text { The social behaviours in } \\
\text { both groups were }\end{array}$ & & \\
\hline
\end{tabular}




\begin{tabular}{|c|c|c|c|c|c|c|c|}
\hline $\begin{array}{l}\text { Virtual reality in } \\
\text { second life } \\
\text { (Kandalaft et al., } \\
\text { 2013) [42] }\end{array}$ & $\begin{array}{l}\text { Individuals } \\
\text { with AS }\end{array}$ & $\begin{array}{l}\text { Emotion } \\
\text { recognition, } \\
\text { Theory of mind } \\
\text { Conversational } \\
\text { skills } \\
\text { In context }\end{array}$ & $\begin{array}{l}\text { Use of a } \\
\text { character in } \\
\text { 3D in } \\
\text { virtual } \\
\text { environmen } \\
t\end{array}$ & $\begin{array}{l}\text { Open pilot study } \\
8 \text { individuals with AS } \\
\text { No controls. } \\
10 \text { sessions over } 5 \text { weeks }\end{array}$ & $\begin{array}{l}\text { Significant improvement } \\
\text { in recognising emotion } \\
\text { from faces and voices. } \\
\text { Some theory of mind } \\
\text { measures improved } \\
\text { significantly. No } \\
\text { significant improvement } \\
\text { in conversational skills } \\
\text { The } 6 \text { month follow-up } \\
\text { questionnaire showed } \\
\text { that participants felt that } \\
\text { they were helped by the } \\
\text { intervention }\end{array}$ & $\begin{array}{l}\text { Use of a protected virtual } \\
\text { island in the online game } \\
\text { Second Life, design not } \\
\text { specific for ASD. }\end{array}$ & 9 \\
\hline
\end{tabular}

ASD=Autism spectrum disorder; HF-ASD=High functioning ASD; LF-ASD=Low functioning ASD; AS=Asperger syndrome; 3D=3 dimensions; IQ=Intellectual quotient; SSQ= Social Skills Questionnaire; ERSSQ=Emotion Regulation and Social Skills Questionnaire. 
Table 3: Serious games targeting general social skills $(\mathrm{N}=15)$ in individuals with autism spectrum disorder

\begin{tabular}{|c|c|c|c|c|c|c|c|}
\hline $\begin{array}{l}\text { Project } \\
\text { (Study } \\
\text { publication) }\end{array}$ & $\begin{array}{l}\text { Targeted } \\
\text { participants }\end{array}$ & Targeted skills & Support & Clinical study & Main results & Models and comments & Total \\
\hline $\begin{array}{l}\text { Collaborative } \\
\text { virtual learning } \\
\text { environment } \\
\text { (Cheng et } \\
\text { al.2010) [16] }\end{array}$ & $\begin{array}{l}\text { Individuals with } \\
\text { HF-ASD }\end{array}$ & Empathy & $\begin{array}{l}3 \mathrm{D} \\
\text { environment } \\
\text { on computer }\end{array}$ & $\begin{array}{l}\text { Open pilot study of } \\
3 \text { boys ages } 8 \text { to } 10 \text { years } \\
\text { with basic cognitive and } \\
\text { reading skills and an IQ }<70 \text {. } \\
40 \text { minute sessions over } 5 \\
\text { months }\end{array}$ & $\begin{array}{l}\text { Each child performed } \\
\text { better on the Empathy } \\
\text { Rating Scale after the } \\
\text { training sessions. }\end{array}$ & $\begin{array}{l}\text { Virtual environment: a fast-food } \\
\text { restaurant }\end{array}$ & 7 \\
\hline
\end{tabular}


(Battochi et al.,

2009a) [7]

(Battochi et al., 2009b) [8]
Experiment : 70 boys with typical development

Experiment 2: 16 boys with ASD
Individuals with Joint attention

ECHOES

2013) [11]

LF- and $\mathrm{HF}$ -

Symbol use

ASD
Digital screen

Open study of

19 children aged 4 to 14

years with ASD and/or other disabilities

Varying number of $15 \mathrm{~min}$ sessions for 6 weeks

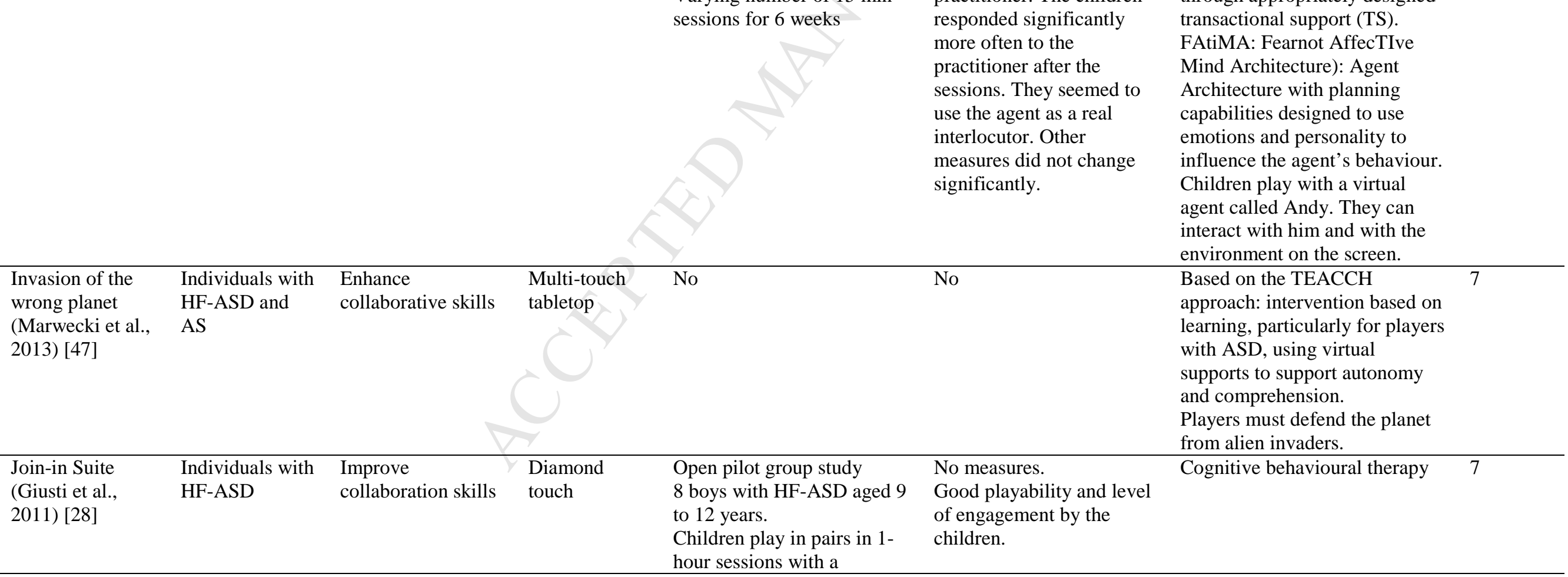




\begin{tabular}{|c|c|c|c|c|c|c|c|}
\hline & & & & therapist. & & & \\
\hline $\begin{array}{l}\text { Kidtalk (Cheng, } \\
\text { 2002) [17] }\end{array}$ & $\begin{array}{l}\text { Individuals with } \\
\text { HF-ASD and } \\
\text { AS }\end{array}$ & $\begin{array}{l}\text { Improve social } \\
\text { skills }\end{array}$ & $\begin{array}{l}\text { Drawings and } \\
\text { texts }\end{array}$ & No & No & & 7 \\
\hline $\begin{array}{l}\text { PAR: } \\
\text { collaborative } \\
\text { multitouch game } \\
\text { (Silva et al, 2014) } \\
\text { [62] }\end{array}$ & $\begin{array}{l}\text { Individuals with } \\
\text { LF- and HF- } \\
\text { ASD }\end{array}$ & $\begin{array}{l}\text { Improve } \\
\text { collaboration }\end{array}$ & $\begin{array}{l}\text { Multi-touch } \\
\text { tabletop }\end{array}$ & $\begin{array}{l}\text { Open pilot group study of } \\
3 \text { boys and } 2 \text { girls aged } 10 \text { to } \\
17 \text { years. They played in } \\
\text { pairs. } \\
\text { Training sessions for } 9 \text { days } \\
\text { over } 1 \text { month. } \\
\text { Testing sessions for } 15 \text { days } \\
\text { over } 6 \text { weeks. }\end{array}$ & $\begin{array}{l}\text { Relevant interactive } \\
\text { situations. } \\
\text { The game encourages } \\
\text { social interactions and } \\
\text { appears to be motivating. }\end{array}$ & $\begin{array}{l}\text { Based on } 4 \text { collaboration } \\
\text { patterns described in Giusti et } \\
\text { al. }(2011) \text {. } \\
\text { Game subject: dress a team of } \\
\text { soccer players. }\end{array}$ & 8 \\
\hline $\begin{array}{l}\text { Raketeer (Van } \\
\text { Veen et al., 2009) } \\
{[68]}\end{array}$ & $\begin{array}{l}\text { Children with } \\
\text { PDD-NOS }\end{array}$ & $\begin{array}{l}\text { Improve basic } \\
\text { collaboration skills }\end{array}$ & $\begin{array}{l}\text { Multi-touch } \\
\text { tabletop }\end{array}$ & $\begin{array}{l}\text { Open pilot study of } \\
13 \text { boys and } 1 \text { girl with ASD } \\
\text { aged } 8 \text { to } 12 \text {. } \\
20 \text { min sessions per day over } \\
4 \text { weeks. }\end{array}$ & $\begin{array}{l}\text { The scale to measure } \\
\text { collaborative skills (filled } \\
\text { by teachers) showed an } \\
\text { increase between the pre- } \\
\text { and post-treatment } \\
\text { sessions. Only one subject } \\
\text { showed a significant } \\
\text { improvement in social } \\
\text { skills in the classroom }\end{array}$ & $\begin{array}{l}\text { Game subject: find elements to } \\
\text { construct a rocket for a } \\
\text { company involved in space } \\
\text { travel. } \\
6 \text { levels }\end{array}$ & 9 \\
\hline $\begin{array}{l}\text { SIDES: Shared } \\
\text { Interfaces to } \\
\text { Develop }\end{array}$ & $\begin{array}{l}\text { Individuals with } \\
\text { AS }\end{array}$ & $\begin{array}{l}\text { Train social skills } \\
\text { through a } \\
\text { multiplayer game }\end{array}$ & $\begin{array}{l}\text { Diamond } \\
\text { touch }\end{array}$ & $\begin{array}{l}\text { Session 1: } 5 \text { male students } \\
\text { with AS (aged } 12 \text { to } 14 \\
\text { years) play } 6 \text { times for } 30\end{array}$ & $\begin{array}{l}\text { Session } 1 \text { allows for } \\
\text { adjustment. }\end{array}$ & $\begin{array}{l}\text { Piaget's theory } \\
\text { Vygotsky's theory }\end{array}$ & 10 \\
\hline $\begin{array}{l}\text { Effective Social } \\
\text { Skills.(Piper et } \\
\text { al., 2006) [54] }\end{array}$ & & & & $\begin{array}{l}\text { min } \\
\text { Session 2: Comparison of } 2 \\
\text { groups: one with four of the } \\
\text { students who know the game } \\
\text { (group 1) and } 4 \text { who do not } \\
\text { know the game (group 2) }\end{array}$ & $\begin{array}{l}\text { Session 2: measures } \\
\text { positive, aggressive and } \\
\text { non-response behaviours } \\
\text { in the presence of rules (no } \\
\text { rules vs computer rules vs } \\
\text { human rules). Games } \\
\text { encourage positive } \\
\text { behaviours. The rules } \\
\text { provided by the computer } \\
\text { appeared more easily } \\
\text { adapted. }\end{array}$ & $\begin{array}{l}\text { Players have to build a pass to } \\
\text { allow a frog to move from a } \\
\text { departure to a finish point. }\end{array}$ & \\
\hline $\begin{array}{l}\text { StoryTable (Gal } \\
\text { et al. 2009) [29] }\end{array}$ & $\begin{array}{l}\text { Individuals with } \\
\text { HF-ASD who } \\
\text { could read and } \\
\text { write }\end{array}$ & $\begin{array}{l}\text { Improve } \\
\text { collaboration skills }\end{array}$ & $\begin{array}{l}\text { Diamond } \\
\text { touch } \\
\text { Virtual } \\
\text { environment }\end{array}$ & $\begin{array}{l}\text { Open pilot group study of } \\
6 \text { children aged } 8 \text { to } 11 \\
\text { years. Play with peers. } \\
8 \text { sessions for } 3 \text { weeks }\end{array}$ & $\begin{array}{l}\text { Few or no autistic } \\
\text { behaviours during the } \\
\text { game. } \\
\text { Children produced more }\end{array}$ & $\begin{array}{l}\text { Manipulate object and } \\
\text { characters, each child has } \\
\text { different characters }\end{array}$ & 10 \\
\hline
\end{tabular}




\begin{tabular}{|c|c|c|c|c|c|c|c|}
\hline & & & & & $\begin{array}{l}\text { positive interactions (look, } \\
\text { negotiate, comfort, etc.) } \\
\text { during free play after } \\
\text { training. }\end{array}$ & & \\
\hline $\begin{array}{l}\text { TeachTown } \\
\text { (Whalen et al., } \\
\text { 2010) [71] }\end{array}$ & $\begin{array}{l}\text { Children with } \\
\text { ASD and a } \\
\text { developmental } \\
\text { age from } 2 \text { to } 7\end{array}$ & $\begin{array}{l}\text { Social and } \\
\text { emotional skills, } \\
\text { language arts, } \\
\text { language } \\
\text { development, } \\
\text { adaptive skills, } \\
\text { cognitive skills, } \\
\text { mathematics }\end{array}$ & $\begin{array}{l}\text { Pictures, } \\
\text { photos, videos }\end{array}$ & $\begin{array}{l}\text { Controlled study of } \\
15 \text { children with ASD who } \\
\text { were trained and compared } \\
\text { with } 25 \text { children with ASD } \\
\text { matched for severity (CARS } \\
\text { score). } \\
20 \text { min per day for } 3 \text { months }\end{array}$ & $\begin{array}{l}\text { Children progressed in the } \\
\text { software program. } \\
\text { Children in the treatment } \\
\text { group performed better } \\
\text { than the control group on } \\
\text { the Brigance Inventory of } \\
\text { Early Development, but } \\
\text { these differences were not } \\
\text { significant. }\end{array}$ & $\begin{array}{l}\text { Applied behaviour analysis } \\
\text { Different lessons with exercises } \\
\text { and tests. }\end{array}$ & 9 \\
\hline $\begin{array}{l}\text { Trollskogen « the } \\
\text { troll forest » } \\
\text { (Zarin et } \\
\text { Fallman, 2011) } \\
\text { [75] }\end{array}$ & $\begin{array}{l}\text { Children with } \\
\text { ASD }\end{array}$ & $\begin{array}{l}\text { Train on behaviours } \\
\text { in social situations }\end{array}$ & $\begin{array}{l}\text { Multi-touch } \\
\text { tabletop }\end{array}$ & $\begin{array}{l}\text { Game designed during work } \\
\text { with } 6 \text { children with ASD or } \\
\text { Down's syndrome aged } 5 \text { to } \\
8 \text { years. } \\
\text { No evaluation }\end{array}$ & No & & 7 \\
\hline $\begin{array}{l}\text { Virtual Café } \\
\text { (Mitchelle et al., } \\
\text { 2006)[48] } \\
\text { (Parson et al., } \\
\text { 2004) [53] }\end{array}$ & $\begin{array}{l}\text { Individuals with } \\
\text { AS }\end{array}$ & $\begin{array}{l}\text { Teach social } \\
\text { understanding }\end{array}$ & Computer & $\begin{array}{l}7 \text { teenagers with AS aged } 14 \\
\text { to } 16 \text { years. } \\
\text { Participants watch } 1 \text { video at } \\
\text { the beginning, one at } 3 \\
\text { weeks and one at the end of } \\
\text { the session, which contains a } \\
\text { real café and a bus, and they } \\
\text { must indicate where they } \\
\text { will sit. They play for } 3 \\
\text { weeks (between video } 1 \text { and } \\
2 \text { or video } 2 \text { and } 3 \text { ) in the } \\
\text { virtual environment. } \\
\text { Comments from } 2 \\
\text { adolescents with AS }\end{array}$ & $\begin{array}{l}\text { One participant had to be } \\
\text { excluded. } \\
\text { The participant took more } \\
\text { time to finish a session on } \\
\text { some levels. } \\
\text { On some levels, the } \\
\text { participant's performance } \\
\text { increased with the number } \\
\text { of sessions. } \\
\text { Choosing a place to sit } \\
\text { during the video sessions } \\
\text { was better adapted after } \\
\text { sessions in the virtual } \\
\text { environment. } \\
\text { Participants enjoyed } \\
\text { playing in the virtual } \\
\text { environment and thought it } \\
\text { could help them in real } \\
\text { life. }\end{array}$ & $\begin{array}{l}\text { Building on the work of Parson } \\
\text { et al. (2004) }\end{array}$ & 9 \\
\hline GOLIAH & Children with & Teach imitation and & Gaming & Open pilot study of & Good participation during & Based on the Early Start Denver & 9 \\
\hline
\end{tabular}




\begin{tabular}{|c|c|c|c|c|c|c|}
\hline $\begin{array}{l}\text { (Gaming Open } \\
\text { Library for } \\
\text { Intervention for } \\
\text { Autism at Home } \\
\text { (Bono et al., in } \\
\text { revision) [13] }\end{array}$ & ASD (IQ>60) & $\begin{array}{l}\text { joint attention } \\
\text { during a } \\
\text { cooperative task }\end{array}$ & $\begin{array}{l}\text { platform (11 } \\
\text { game in total) } \\
\text { on two } \\
\text { connected } \\
\text { computers or } \\
\text { tablets (one } \\
\text { for the patient, } \\
\text { one for the } \\
\text { parent or } \\
\text { therapist) }\end{array}$ & $\begin{array}{l}5 \text { children with ASD aged } 5 \\
\text { to } 9 \text { years. } \\
\text { A } 1 \text {-hour session } 4 \text { times per } \\
\text { week for } 6 \text { weeks over } 3 \\
\text { months. }\end{array}$ & $\begin{array}{l}\text { the study }(\sim 80 \%) \text {. } \\
\text { All children completed all } \\
\text { of the games. } \\
\text { The number of sessions } \\
\text { dedicated to each game } \\
\text { varied and could be } \\
\text { tailored through automatic } \\
\text { scoring. } \\
\text { Parents (55\%) observed } \\
\text { enhanced parent-child } \\
\text { relationships. }\end{array}$ & $\begin{array}{l}\text { Model (Rogers and Dawson, } \\
\text { 2009) }\end{array}$ \\
\hline
\end{tabular}

$\mathrm{ASD}=$ Autism spectrum disorder; HF-ASD=High functioning ASD; LF-ASD=Low functioning ASD; AS=Asperger syndrome; 3D=3 dimensions; IQ=Intellectual quotient;

PDD-NOS=Pervasive developmental disorder-not otherwise specified; CARS=Children autism rating scale; TEACH: Treatment and Education of Autistic and Related

Communication-Handicapped CHildren. 


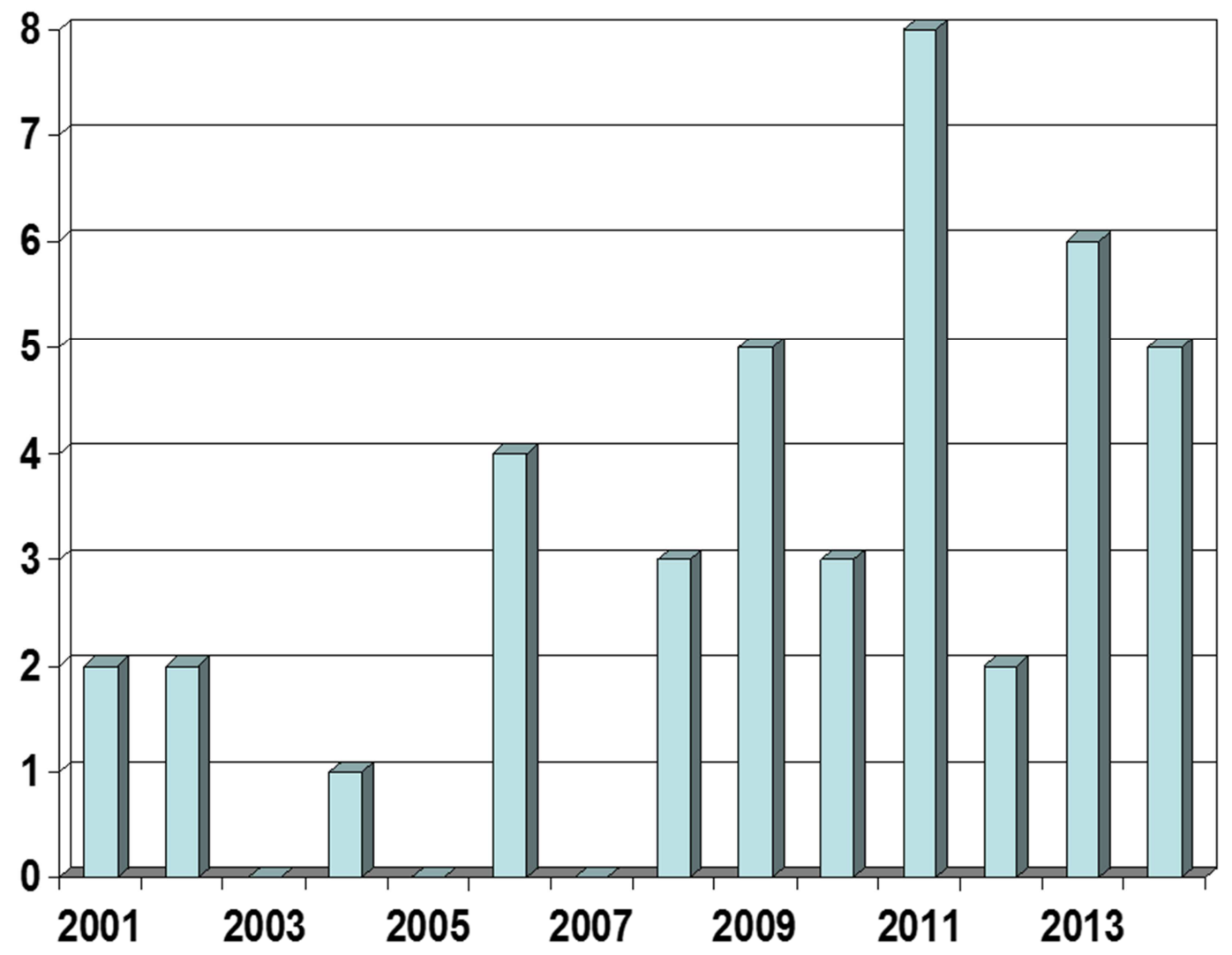


Connolly ( $\max =15$ ) and $\square$ Yusoff ( $\operatorname{Max}=\mathbf{2 4}$ ) scale total scores according to the 31 games training social interaction and emotions to people with ASD

25

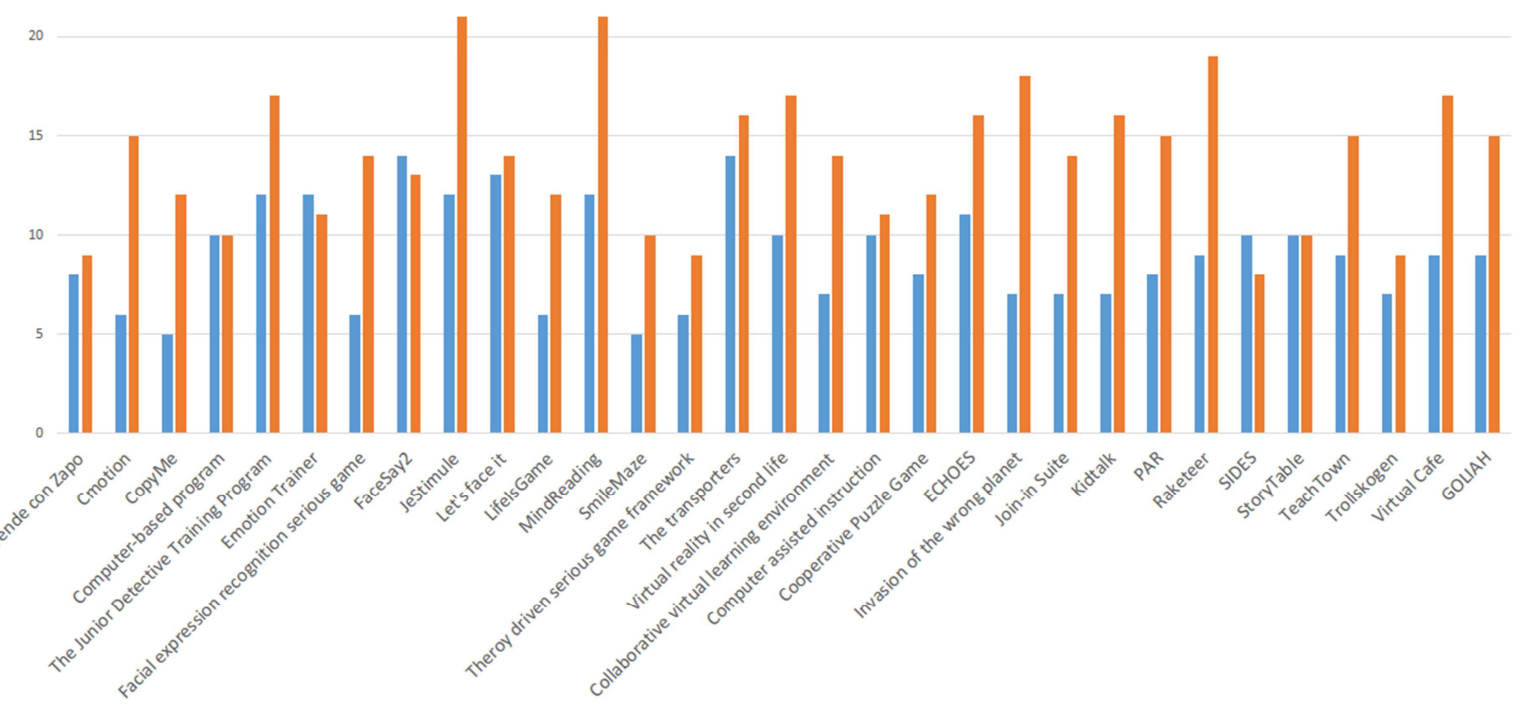


Screening of the following databases with autism or ASD AND "serious games" or "video games" or "virtual reality" or games

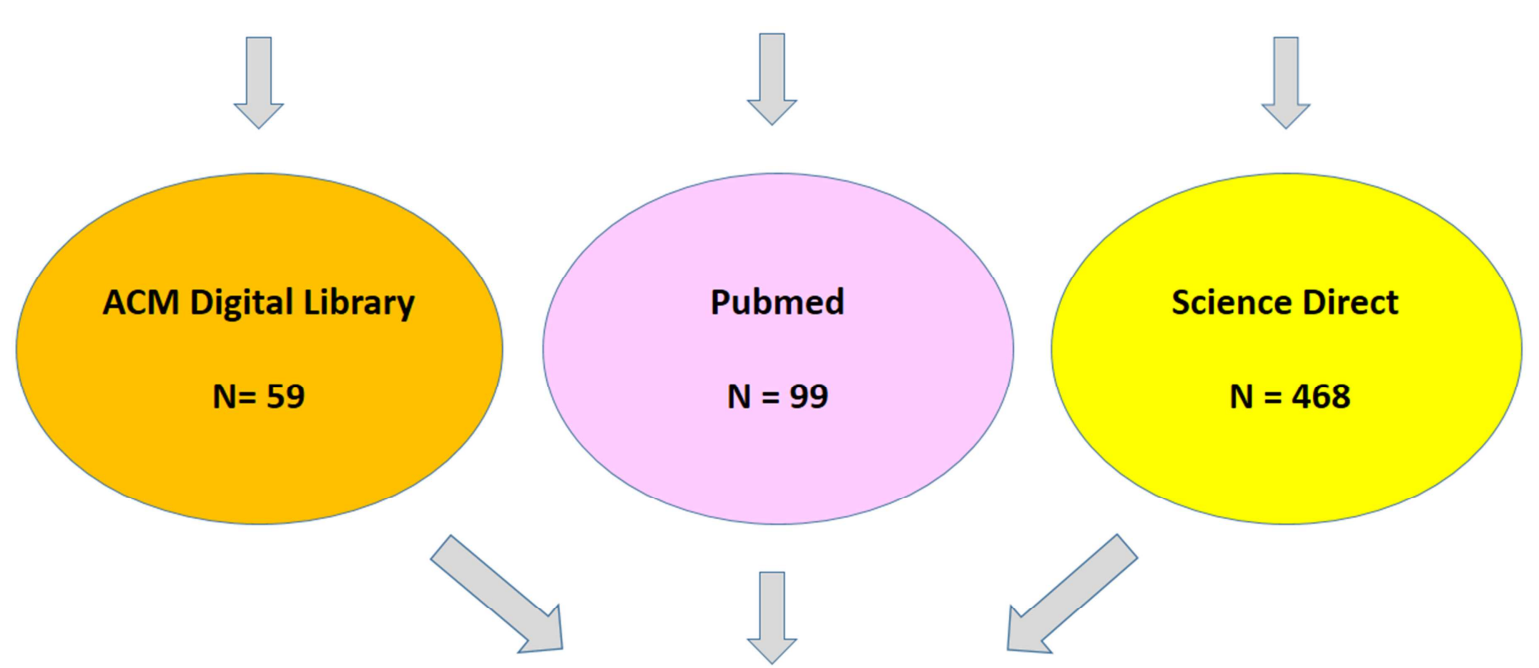

Total data set

$\mathrm{N}=626$

Systematic search through

abstracts

Additional reports through sreening relevant papers and reviews $(\mathrm{N}=2)$

2 reports from our group

Excluded papers:

Review (N=12)

Only abstract available ( $N=76)$

Other topics ( $\mathrm{N}=498)$

- Other $(\mathrm{N}=4)$

Total relevant papers

$\mathrm{N}=\mathbf{4 0}$ 


\section{Highlights}

- The paper reviews 31 serious games targeting social abilities for ASD

- It provides brief overview and assessment of the 31 games in terms of clinical validation and playability/game design

- It lists current limitations about serious games targeting social skills and emotion recognition for ASD

- It proposes future research agendas to improve serious games validity for ASD 
Conflicts of interest: CG, OG and KB have no conflict of interest to declare. ALJ and DC participated in GOLIAH serious game platform development. SS participated in JeStimule serious game development. However, ALJ, DC and SS were all working for public University with non-profit contract. These previous researches were conducted in the absence of any commercial or financial relationships that could be considered as a potential conflict of interest.

Funding: This work was supported by the Agence Nationale pour la Recherche (ANR) in the frame of its Technological Research CONTINT program (JEMImE, project number ANR-13CORD-0004), by the European Commission (FP7: MICHELANGELO under grant agreement no. 288241), and the Fondation Initiative Autisme 